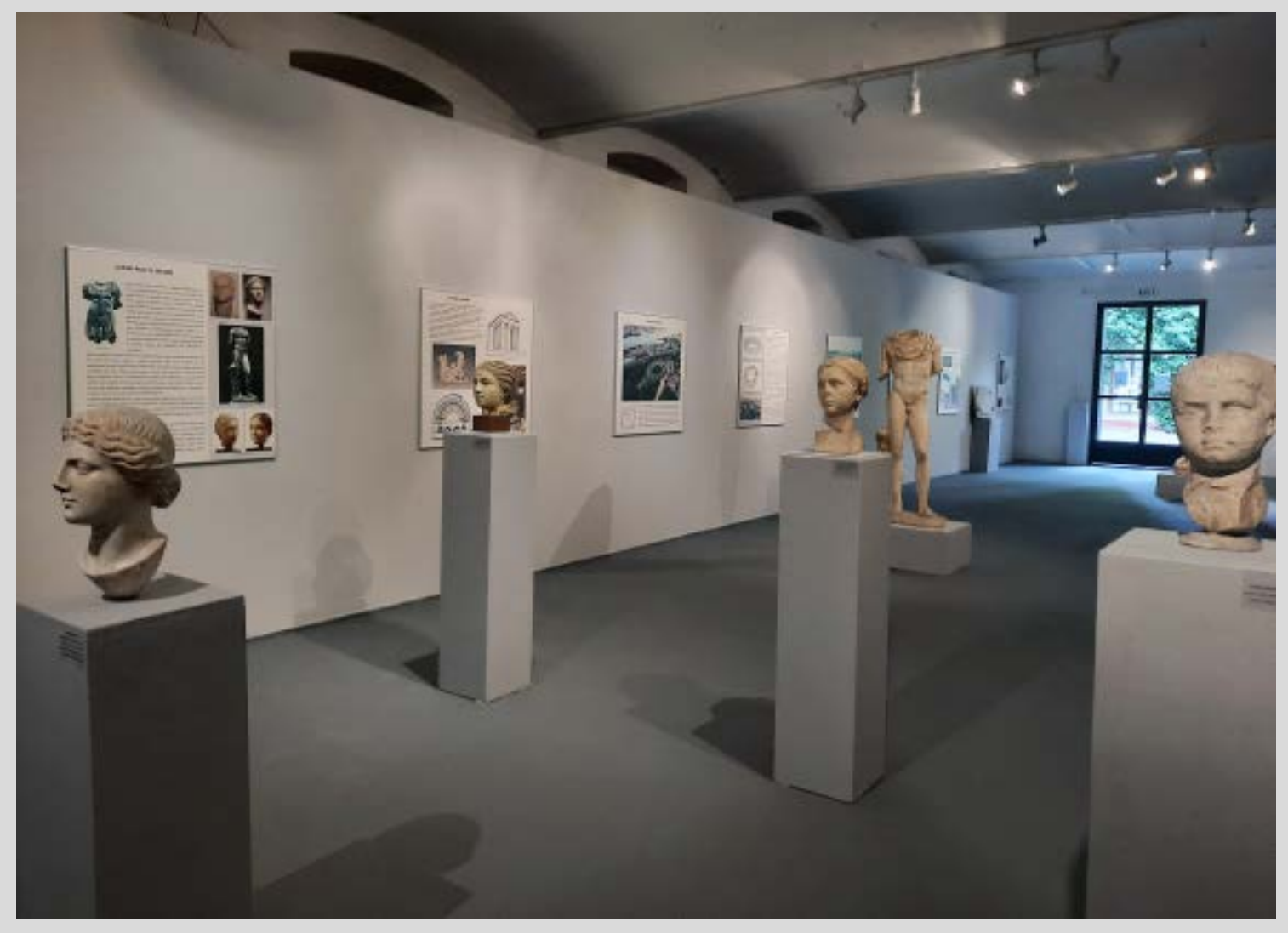




\section{Je li izložba Skulptura antičke Salone iz fundusa Gliptoteke HAZU bila nagovještaj sretnije budućnosti ovog specijaliziranog umjetničkog muzeja?}

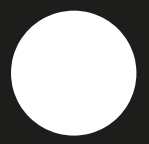

Skulptura antičke Salone iz fundusa Gliptoteke HAZU, Gliptoteka HAZU-a, Zagreb, 5. lipnja -4. srpnja 2021. DOI: 10.31664/zu.2021.108.08

Oprostorenje i djelovanje uskoro 85-godišnje Gliptoteke HAZU-a, tog našeg jedinog specijaliziranog muzeja posvećenog sabiranju i izlaganju gipsanih odljeva i kiparskih radova (izuzmemo li monografske galerije kipara poput Galerije i Ateljea Meštrović, Galerije Antuna Augustinčića i druge), našla nam se ove godine u fokusu zbog dva kulturna događanja-prije svega zbog izložbe Skulptura antičke Salone iz fundusa Gliptoteke HAZU koju su autorski potpisale Magdalena Getaldić i dr. sc. Jasna Jeličić Radonić te zbog obilježavanja 110. godišnjice rođenja osnivača Gliptoteke dr. sc. Antuna Bauera (1911. - 2000.), koja se planira održati u obliku skupa u prosincu 2021. u Zagrebu. Važnost profesora Bauera-od 1966. sudjelovao je u nastavi na poslijediplomskom studiju bibliotekarstva, dokumentacije i informacijskih znanosti pridodajući mu usmjerenje muzeologije i stoga ga s pravom i mi tako nazivamo - nama koji smo u području kulture i umjetnosti nazočni desetljećima, jasna je i neupitna, no mlađim generacijama, vezanima uz sadržaj interneta i društvenih medija, njegova su postignuća svedena na mali broj, ponekad samo na spašavanje Fernkornove skulpture bana Josipa Jelačića, što doživljavamo iskrivljenim sagledavanjem pod utjecajem suvremenih promjena društvenih moći.
Sl. I Detalj izložbe vezan uz tematsku jedinicu Carski kult u Saloni. Foto: Ž. Vujić

\section{Żarka Vufić}

Odsjek za komunikacijske i informacijske znanosti, Filozofski fakultet Sveučilišta u Zagrebu 
Popis muzejskih i galerijskih institucija u čijem je osnutku Bauer imao veće ili manje učešće nije zanemariv-od nama važne Gliptoteke 1937., pa do vidljivog napora početkom 90-ih godina 20. stoljeća da se u manjim mjestima poput Novske ili Jastrebarskog osnivaju likovne galerije, ${ }^{1}$ zanimljiv je niz koji bi bio dostatan da se ispuni jedan profesionalni život. No u smislu organiziranja cjelokupne muzejske i likovne djelatnosti u Hrvatskoj ipak bismo se usudili istaknuti ne neku od spomenutih inicijativa, nego osnutak Muzejskog dokumentacijskog centra 1955., jedinstvene referentne institucije u ovom dijelu Europe, te Arhiva za likovne umjetnosti HAZU-a tijekom Drugoga svjetskog rata (započeo je postojati kao arhiv Gipsoteke), kao doista vizionarske kulturne pothvate. Objema institucijama Bauer je potvrdio svoje razumijevanje važne uloge stvaranja, očuvanja i uporabe dokumentacije koja se tiče kulturnih djelatnosti i njezinih sudionika. Kad tome pribrojimo činjenicu da je 1953. pokrenuo (privatno) prvi muzeološki časopis Muzeologija te sudjelovao u samim počecima informatizacije kulturnih i muzejskih ustanova sredinom 70-ih godina, jednako tako stajao na strani razvijanja edukativne djelatnosti, ali i promidžbe te odnosa s javnošću u našim muzejima, samo smo ovlaš ocrtali lik nevjerojatnog pionira i upornog pratitelja suvremenih profesionalnih praksi.

No u ovoj prigodi vratit ćemo se njegovim profesionalnim počecima, o kojima je 1994. uvjerljivo i s razumijevanjem pisala njegova bliska suradnica mr. sc. 2 Branka Šulc. ${ }^{2}$ Dakle, geneza Bauerove naklonosti prema likovnim umjetnostima te prema muzejima kao institucijama kulture došla je iz dvaju motivirajućih izvora. Jedan predstavljaju same Bauerove likovne vještine, koje je u formativnom razdoblju pohađanja osječke gimnazije uočio i poticao gimnazijski nastavnik crtanja i slikar lco Jung. On je mladom Baueru pomogao da se likovno izražava crtanjem, slikanjem, ali i modeliranjem, što ga je kasnije i dovelo na studij povijesti umjetnosti i arheologije na Filozofskom fakultetu u Zagrebu. Drugi važan utjecaj nazire se u osobnosti kustosa tadašnjeg Gradskog muzeja Osijek Vjekoslava Celestina i susretima ovog predanog muzealca i numizmatičara s jednim gimnazijalcem. No za osnutak Gliptoteke presudnu je ulogu imao i treći detalj-činjenica da je Bauer kao student 30-ih godina 20. stoljeća dobio zadatak organizirati rad Arheološkog instituta u Zagrebu, koji je imao obvezu brinuti se i za nesređenu zbirku gipsanih odljeva antičke plastike (danas dostupna dijelom na Filozofskom fakultetu u Zagrebu, dijelom u Gliptoteci) te očuvati specijaliziranu knjižnicu i fototeku. Tako Bauer sve do 1942. obavlja i dužnost demonstratora i asistenta na Katedri za arheologiju koji se brine i za preživjele preostatke spomenute Zbirke odljeva.

Kad bismo detalje ranog razdoblja Bauerova života usporedili s onima drugog poznatog osječkog gimnazijalca Izidora Kršnjavoga (1845.-1927.), kojeg smatramo konceptualnim začetnikom Gliptoteke-ideja i tlocrt Gypsmuseuma po njemu su osmišljeni u okviru projekta srednjih škola na Rooseveltovom trgu (!) - naišli bismo na dosta podudarnosti-od sposobnosti likovnog izražavanja i modeliranja do sposobnosti organiziranja institucija i velikog interesa za muzejsku djelatnost. Napokon, obojica su u formativnim godinama boravila u Beču, Kršnjavi pohađajući studij povijesti umjetnosti (1866.-1870.), dok je Bauer od 1935. do 1936. tamo pripremao svoj doktorat pod naslovom Rimska olovna plastika (s posebnim naglaskom na nalazima iz Siska) te su obojica mogla vidjeti i spoznati ulogu Zbirke antičkih gipsanih odljeva za Likovnu akademiju i kulturu Beča općenito. Naravno, obojica su poznavala iz prve ruke zgradu, fundus i djelovanje minhenske Gliptoteke, koja se prvenstveno temelji na originalnim antičkim kiparskim ostvarenjima za koja Ludwig I. Bavarski nije štedio ni osobnu ni državnu blagajnu.

No, za razliku od Kršnjavoga, Antun Bauer posjedovao je iznimno jak kolekcionarski nagon koji ga nije napuštao ni u dubokoj starosti. Strast za sabiranjem umjetničkih djela već ga je u gimnazijsko doba dovela do gipsanih odljeva-s obzirom na to da nije imao novca za kupnju medalja i plaketa, uzimao bi u plastelinu
Čučković, „Što više galerija!", $92-95$.

Šulc, ,Višestrukost stručnog i znanstvenog djelovanja”, 5-8. 
otiske odabranih djela te ih kasnije odlio u gipsu. ${ }^{3}$ Kao student prikupljao je i kiparske, dobrim dijelom i studentske radove-gipsane modele kao originalna svjedočanstva određenih plastičkih zamisli-polaznika Likovne akademije u Zagrebu, od kojih su mnogi kasnije postali važnim hrvatskim kiparima. Na taj način i jest nastala njegova oveća privatna zbirka moderne plastike i sitnijih odljeva koju je donirao 1937. Gradu Zagrebu pod uvjetom da joj se osigura dostojan prostor, ali i da se profesionalno nastavi brinuti za nju. Tako je zapravo jedan entuzijastičan 26-godišnjak, zaljubljen u likovnu umjetnost i trajno određen sabiranjem kao sekundarnom ljudskom potrebom, svojom zbirkom osmislio i osigurao i svoje radno mjesto.

No toj zbirci osigurao je i primjeren izložbeni i čuvaonički prostor, što Kršnjavome nikada nije uspjelo što se tiče Zbirke odljeva antičkih skulptura. Zanimljivo je kako je prvi pokušaj prostornog zbrinjavanja Zbirke bilo idejno arhitektonsko rješenje za gradnju nove izložbene zgrade koje je potpisao Bauerov vršnjak Andro Mohorovičić (1913.-2002.). Mislimo pri tome na paviljon za Muzej sadrenih odljeva koji je trebao imati veliku središnju dvoranu i nekoliko manjih te biti izgrađen od betona i stakla. ${ }^{4}$ (SI.2) Na perspektivnom prikazu predočenom širokoj javnosti doista je vidljivo kako je Mohorovičić predvidio jednostavnu, ali monumentalnu bazilikalnu zgradu većih dimenzija-lako je napraviti usporednicu jer je unesena veličina ljudskog lika (!) - koja je mogla dostojno prihvatiti i veće gipsane odljeve te maksimalno koristiti dnevnu rasvjetu iz dugih horizontalnih prozorskih osi (ponašanje gipsa pod utjecajem dnevnog svjetla tada još nije uzimano u obzir). Jače naglašavanje ulazne fronte dvama stupovima te velikim skulpturama na fasadi nižih krila svoje rješenje kao da duguje i onodobnom njemačkom monumentalizmu. Tek kad se nije uspjelo osigurati financijske uvjete za gradnju, Bauer kreće u potragu za postojećim praznim zgradama u blizini samog srca grada. I tada dolazi do odabira preostalog dijela kompleksa kožare na Novoj Vesi, tog prvog, čini se ne samo europskog primjera smještaja umjetničkog muzeja u napuštenu industrijsku arhitekturu.

Naime, prema našim istraživanjima za potrebe nastave, ${ }^{5}$ tek je tijekom 70 -ih godina 20. stoljeća, prepoznatih kao razdoblje jedne od niza kriza muzeja, došlo i do propitivanja muzejskih zgrada i galerijskih prostora, i to od strane umjetnika, što Milojković i Nikolić povezuju s odgovorom umjetnika na umjetno stvorene prostore, tzv. bijele kocke ili klinike, neutralne, ali i bez identiteta, u kojima je kontempliranje nad estetskim vrijednostima umjetničkih djela imalo prioritet. ${ }^{6}$ Rani iskaz koji svjedoči o tome povezujemo, između ostalih, i s britanskim umjetnikom Johnom Piperom (1903.-1992.). Godine 1971. Piper izjavljuje kako su mu institucionalni prostori za prezentiranje umjetnosti potpuno neučinkoviti jer su previše određeni i izolirani te kao takvi izazivaju prestandardizirane odgovore (u posjetitelja) na ono što je u njima predstavljeno. ${ }^{7}$ Rješenje je za to pronalazak alternativnih prostora za izlaganje, a takvima svakako pripadaju i zgrade i prostori industrijskih kompleksa, čija prenamjena za obavljanje funkcije umjetničkih muzeja započinje upravo sredinom 70-ih godina -čini se kako tada počinje i dodjeljivanje značenja baštine industrijskoj arhitekturi i pogonima (!) -i ojačava svakim novim desetljećem. Primjerice, početkom 80-ih Frank Gehry za potrebe privremenog postava Muzeja suvremene umjetnosti u Los Angelesu naslovljenog Temporary Contemporary-dok se čeka dovršetak izgradnje muzejske zgrade Arate Isozakija - minimalno intervenira u vanjštinu i unutrašnjost velikoga skladišnog prostora na rubu skladišnog distrikta u LA-u iz 40-ih godina 20. stoljeća. Tako nastaje izložbeni prostor koji danas poznajemo kao The Geffen Contemporary at MOCA LA. ${ }^{8} \mathrm{U}$ isto to vrijeme u Milanu unutar veće urbane obnove industrijske četvrti Bicocca nastaje trodjelni kompleks Pirelli HangarBicocca unutar kojeg je nekadašnja radionica za popravak lokomotiva uređena u izložbeni prostor (Cubo), manja ciglena industrijska zgrada (Shed) ima funkciju ulaznog prostora s osnovnim servisima za posjetitelje, dok se u trećoj, trideset metara visokoj zgradi (Navate) nalazi poznata Kieferova skulpturalna instalacija The Seven Heavenly Palaces. ${ }^{9}$
Mažuran-Subotić, „Dr. Antun Bauer kao osnivač Gipsoteke u Zagrebu”, 82.

Bauer, Gipsoteka 1937.-1947., 9I.

5

Misli se na nastavu na kolegiju Arhitektura muzeja u sklopu diplomskog studija muzeologije i upravljanja baštinom na Filozofskom fakultetu u Zagrebu.

\section{6}

Milojković, Nikolić, „Museum Architecture and Conversion: From Paradigm to Institutionalization of Anti-museum", 74 .

\section{7}

Cavallero, Literature review. The adaptive reuse of former industrial buildings as museum spaces: Positive aspects, challenges and difficulties, 4 .

„Tectonic Arts. Frank Gehry talks with Julian Rose".

9 „Pirelli HangarBicocca: History of the Building". 

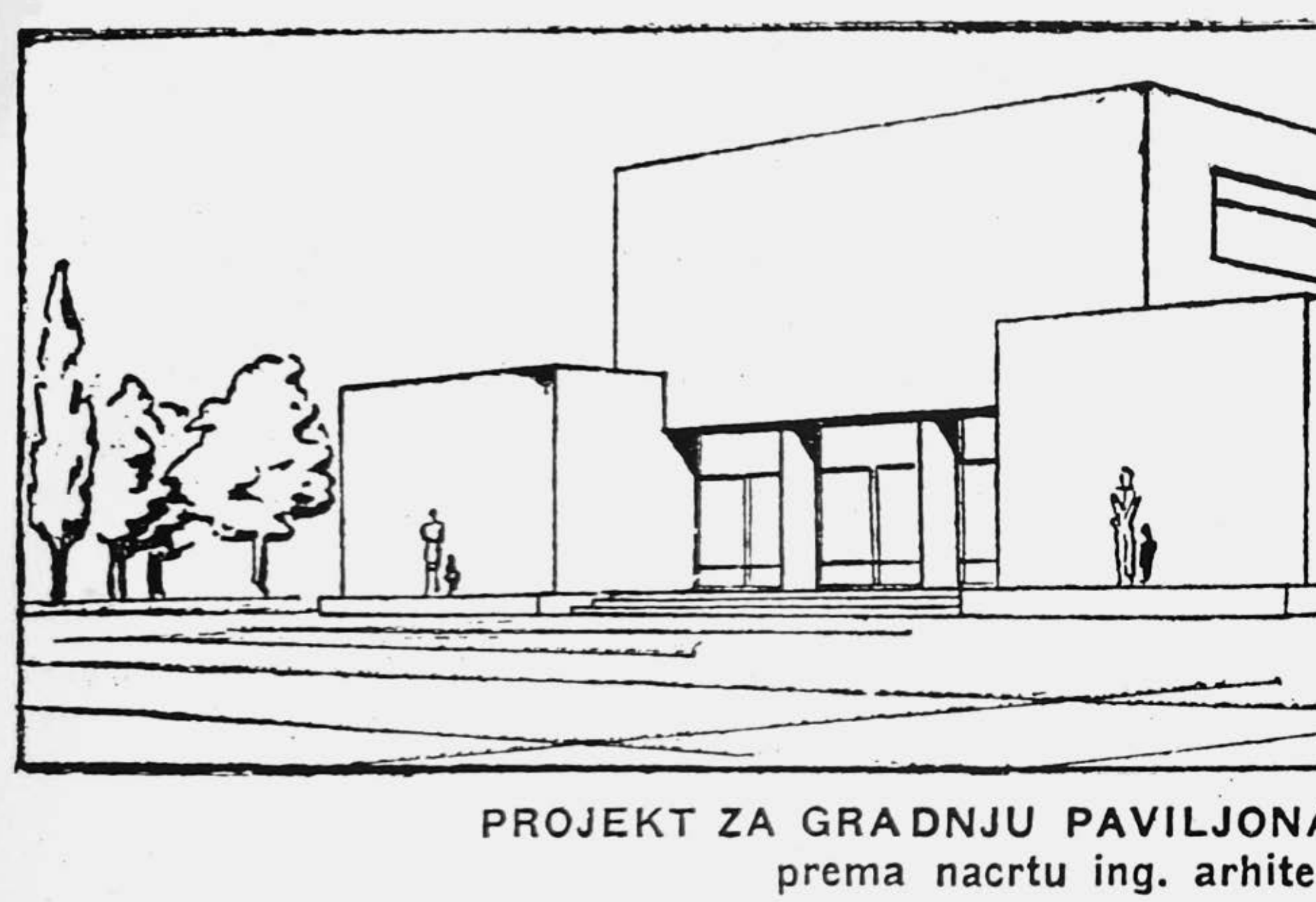


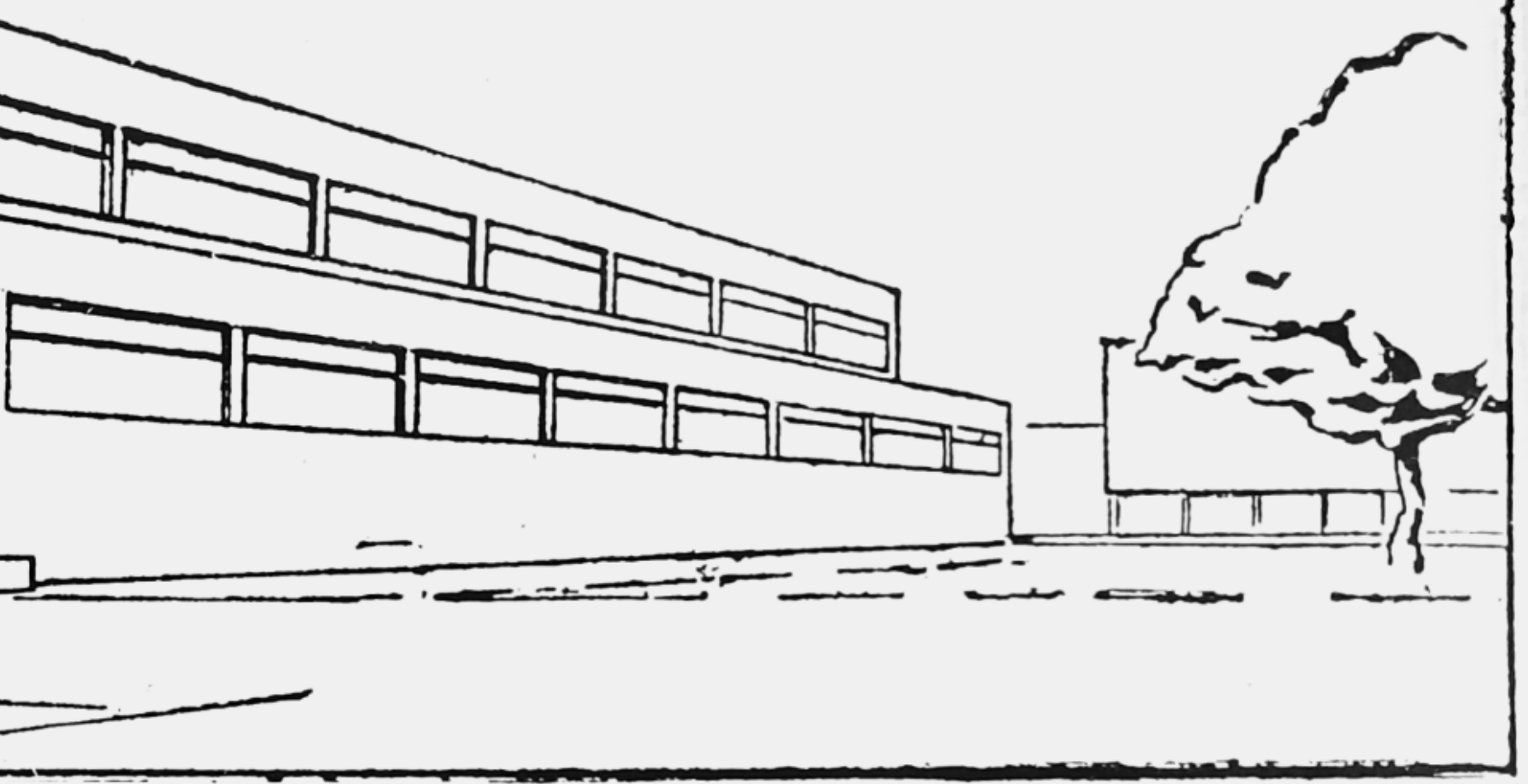

\section{A MUZEJA SADRENIH ODLJEVA kta Andre Mohorovicica}

Sl. 2 Idejno rješenje za zgradu Gipsoteke, dia. Andre Mohorovičića (presnimka iz: 7 dana I (I938.), 2). 
Krajem 90-ih, uz manje zahtjevne izložbene prostore, učestali su projekti preuređenja industrijske baštine za potrebe velikih umjetničkih muzeja, primjerice kao što je to The Massachusetts Museum of Contemporary Art (MASS MoCA), koji se smjestio u velikom tvorničkom kompleksu čije se preuređenje događalo u razdoblju od četvrt stoljeća i u tri etape. Prvo je 1999. otvoren dio od 19 galerijskih prostora, s mišlju osiguranja izlaganja velikih djela minimalističke umjetnosti, da bi kasnije došlo do promjene poslanja (stvoriti prostor ne samo za prezentiranje nego i za stvaranje umjetničkih djela), kao i do prvog proširenja 2008., a potom i drugog 2017., kojim se proces završio. Čitajući karakteristike i analizirajući fotografije zadnje uređenog prostora 6, prvotno namijenjenog djelovanju jednog industrijskog mlinskog postrojenja s mnoštvom stupovlja i sl., naslućujemo kako su arhitekti studija Bruner-Cott-and-Associates imali relativnu slobodu u mijenjaju izvornih struktura, no kako su najviše što je bilo moguće poštovali duh industrijske zgrade i nastojali ga očuvati. ${ }^{10}$ Negdje u tom razdoblju poznati dvojac Jacques Herzog i Pierre de Meuron za potrebe Galerije Tate Modern preuređuje električnu centralu Bankside na južnoj obali Temze u Londonu. (SI. 3)

Oba su arhitektonska tima smatrala industrijske komplekse koje su preuređivali baštinom zajednice, vrijednom čitanja i novog interpretiranja te osmišljavanja nove uporabe. Njihove bitne značajke ostale su sačuvane, što se zapravo ne može reći za četiri zgrade kompleksa kožare koje je Bauer smatrao prihvatljivim prostorom za potrebe smještanja Gipsoteke. Naša je premisa da se to dogodilo jer tada još nije bilo došlo do tzv. baštinizacije kožare i iz toga je proizašla činjenica da je početno uređenje neposredno nakon Drugog svjetskog rata uključilo ne samo rješavanje smradnih bazena (postrojenja za štavljenje kože) nego i rušenje većeg dimnjaka, ulaznog sklopa stražarnice, zatrpavanje liftova i sl. ${ }^{11}$ (SI. 4) Prvobitna industrijska namjena, osim u odabiru cigle kao jeftinog materijala za brzo podizanje zgrada te prozorskih otvora rješavanih karakterističnim rešetkastim staklenim površinama, ostala je vidljiva u tragovima stupovlja na visokim postamentima u prizemlju zapadne zgrade, u ostacima tračnica u dvorištu, kao i dvama spojnim rampama prvih katova zapadne i istočne zgrade. U svakom slučaju, povijest kompleksa i njezini tragovi, kao i spomenuti herojski napor uređenja za funkcionalni muzej gipsanih odljeva, dokumentiran sačuvanim fotografijama, trebat će ugraditi u budući suvremeni postav koji ova generacija djelatnika Gliptoteke mora odraditi.

Naime, poznato je zainteresiranoj javnosti da su i zgrade same Gliptoteke, ali i njezina građa, stradali u proteklim potresima, kako zagrebačkima tako i u onima s epicentrom na Baniji. Kao i u svakoj nesreći, tako se i u ovoj skriva i element ne samo uklanjanja njezinih posljedica nego i početak promjena koje nose dalekosežnu dobrobit ovoj kulturnoj instituciji. Pri tome mislimo na najavljenu konstrukcijsku obnovu zgrada Gliptoteke, a koja je nezamisliva bez ostvarenja dobrobiti u smislu osiguranja boljih prostornih uvjeta za građu i osoblje, ali i boljih uvjeta za raznolike oblike komuniciranja i interpretiranja gipsanih odljeva i ostale kiparske građe javnostima. U okviru potonjeg, naravno, razmišlja se o boljem koncipiranju i razmještanju pojedinih segmenata djelatnosti u prostoru (funkcionalnije zoniranje), stvaranju kružnog ophoda postavom uz upotrebu postojećih rampi u uličnoj i istočnoj zgradi, uspostavljanju studijskih depoa koji bi također bili dostupni javnostima, jednako tako i o činjenju postupka restauracije i samog nastanka gipsanih odljeva vidljivim za posjetitelje u sjevernoj zgradi itd. Naravno, ne treba odustati ni od parka sa skulpturama (mali projekt akademika Miroslava Begovića uz južni zid kompleksa iz 1999./2000.), a mislimo kako ima mogućnosti i za razmišljanje o uređenju jednog manjeg rezidencijalnog prostora za boravak i djelovanje suvremenih umjetnika unutar Gliptoteke, kojim bi se ojačala veza institucije s recentnim stvaranjem. O svemu tome trebalo bi na idejnoj razini progovoriti u Muzeološkoj koncepciji Gliptoteke, koja bi trebala u sebi uključiti i koncepciju stalnog i studijskog postava.
10

„ArchDaily: MASS MoCA Building 6 / Bruner/ Cott \& Associates". Ovdje spominjemo i primjer povremene izložbe mramornih skulptura iz Kapitolinskog muzeja pod naslovom Mašine i bogovi, a koja je bila zbog radova u matičnom prostoru pripremljena u prvoj električnoj centrali Montemartini u Rimu I997., da bi 200I. taj prostor, prepun kontrasta između očuvane industrijske i antičke skulpturalne baštine, zahvaljujući interesu posjetitelja, postao stalnom muzejskom ekspoziturom spomenutog muzeja.

\section{1}

Bit će zanimljivo u nekoj drugoj prilici načiniti usporedbu Bauerova pristupa uređenju Kompleksa Kožare s kraja 30-ih i kompleksu Gredeljevih radionica za potrebe Hrvatskoga željezničkog muzeja s početka 9o-ih godina 20 . stoljeća, kada je bio aktivan u Odboru za osnivanje željezničkog muzeja u Zagrebu. 


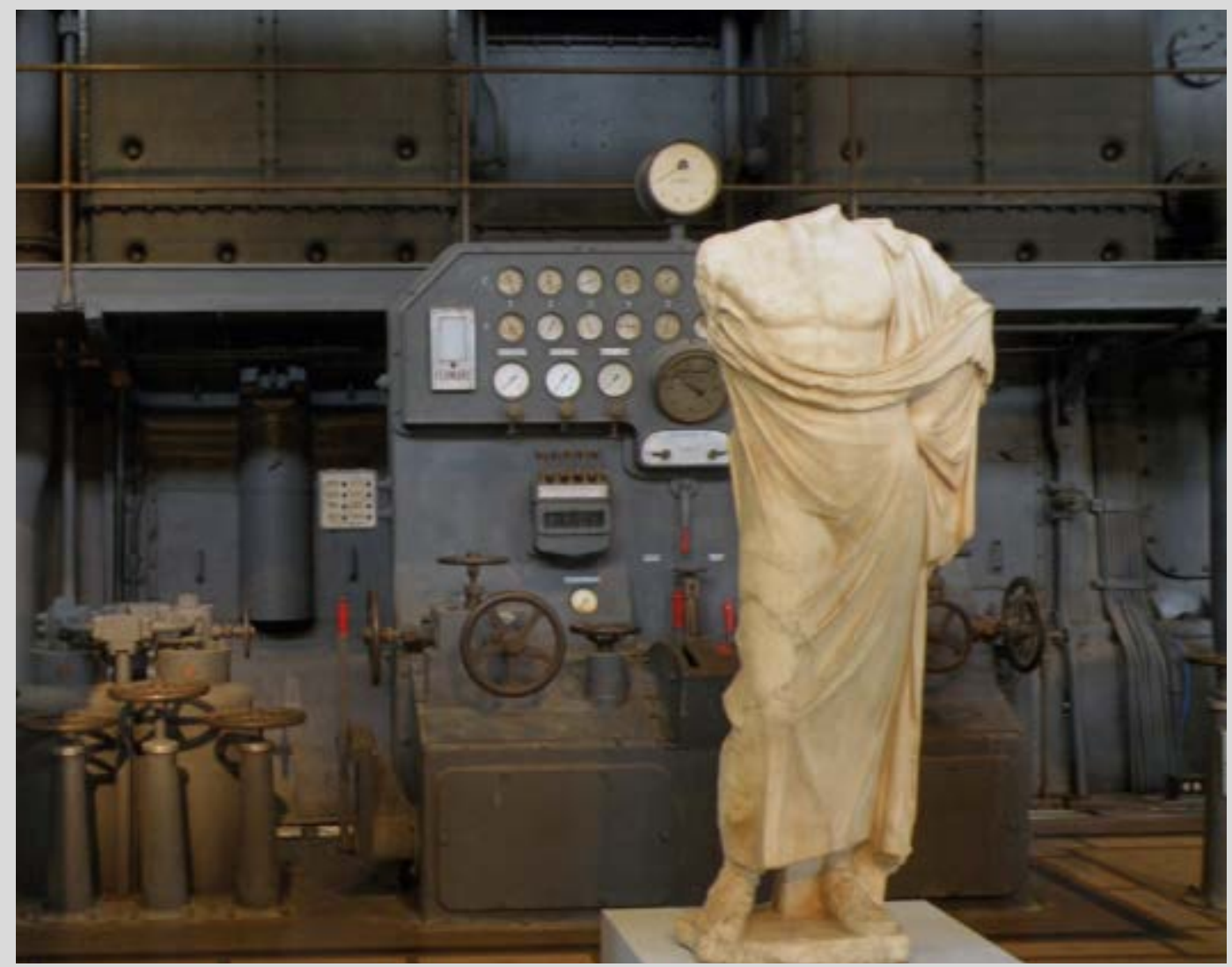

Sl. 3 Detalj izložbe Mašine i bogovi postavljene u Električnoj centrali Montemartini u Rimu. FOTO: A. Barić.

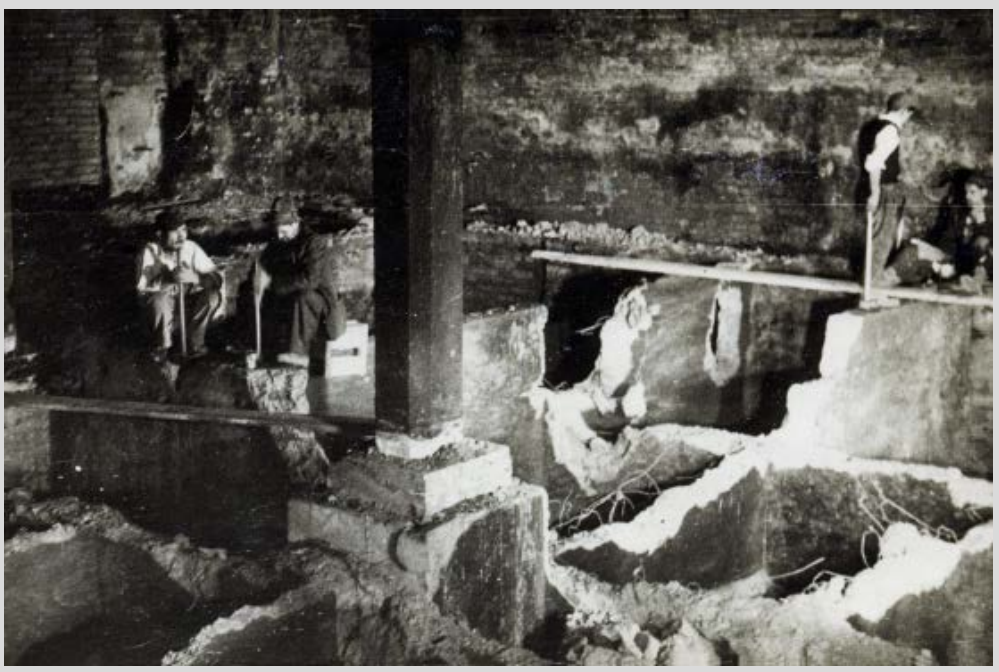

Sl. 4 Adaptacija prizemlja dvorišne zgrade Gipsoteke, I947. Fototeka Gliptoteke HAZU, inv.br. F-9I. 
Pristup interpretiranju u postavima svakako pripada scenariju postava, čiji će razvoj morati uslijediti u nekoj kasnijoj dionici uređenja ustanove. Za njega muzejsko osoblje Gliptoteke ima dovoljno vremena, no čini se kako su se i izložbama počeli pripremati za njega, što smo prepoznali u spomenutoj izložbi-izložbi o skulpturi antičke Salone, koju doista možemo shvatiti i kao testiranje određenih interpretacijskih strategija koje bi mogle biti primijenjene u stalnom postavu. Prije svega to je strategija kontekstualizacije. Tu mislimo na odluku da se najbrojniji gipsani odljevi u Zbirci sadrenih odljeva antičkih spomenika, oni koji su godinama rađeni prema kamenim spomenicima pronađenima na lokalitetu antičke Salone, prikažu upravo preko osvještavanja konteksta Salone: od povijesti sakupljanja salonitanskih ostataka u privatnim zbirkama, preko prvih istraživača lokaliteta, kao i važnih gradskih cjelina i građevina te ostalih s njima povezanih relevantnih tematskih slojeva. Svi ovi elementi poslužili su za tematsku raščlambu izložbe, a strategija kontekstualizacije, bez imalo dvojbe, pronašla je svoj odjek i u plakatu izložbe. (SI. 5)

Glede koncipiranja izložbe, kreativne snage udružile su jedna muzejska profesionalka-Magdalena Getaldić, kustosica Gliptoteke-i jedna istraživačica Salone - prof. dr. sc. Jasna Jeličić Radonić. No one su odgovorne i za oblikovnu razinu izložbe, s obzirom na to da dizajner nije bio angažiran, a što se, vjerujemo, pri realizaciji novog postava neće dogoditi.

Izložba je bila pripremljena za veći prizemni prostor zapadne zgrade koji se često upotrebljava za povremeno izlaganje suvremenih hrvatskih umjetnika, dok su izložbe koje koriste identitetski važnu građu Gliptoteke daleko rjeđe te zato i zaslužuju našu pažnju. Prostor je podijeljen ostacima industrijskih stupova na dva uzdužna dijela koji omogućavaju dvosmjerno ovladavanje prostorom i sadržajima, slijeva udesno i zdesna ulijevo. Autorice su se odlučile za prvu mogućnost. Kao uvod u izložbu trebao je poslužiti na zidu projicirani virtualni sadržaj o Zbirci odljeva antičke skulpture, koji se mogao shvatiti i kao promocija virtualnog prikaza načinjenog uz izložbu, stalno dostupnog dugo poslije zatvaranja izložbe. No bilo bi zanimljivo znati jesu li posjetitelji uočili tu logiku prezentiranja koja je pošla od šire cjeline-cjelokupne Zbirke-do njezina dijela-19 odljeva koji pripadaju lokaciji Salone, o kojima je progovorila prva tekstualna legenda kojom je započela prezentacija na istočnom zidu. Povezano s budućim postavom, nema sumnje kako će tu ulogu uvodne intelektualne pripreme, pogotovo za mlađe posjetitelje, morati odigrati i planirana otvorena radionica za izradu sadrenih odljeva i kreativno interpretiranje uloge sadrenih odljeva tijekom vremena, koji su se upotrebljavali ne samo u umjetnostima te pri restauraciji i edukaciji nego i u nekim djelatnostima sve do danas. Jedna od posjetiteljima zanimljivijih, pa i neobičnih (!) funkcija može biti i ona pogrebna. Mislimo ovdje na povijesno dugo prisutnu izradu posmrtnih maski putem uzimanja otiska u gipsu, što je bio sastavni dio i naše kulture umiranja do sredine 20. stoljeća. ${ }^{12}$

Razmjerno velika dimenzija početne uvodne legende na zidu pokazuje s jedne strane odabrani modul-tek je nekoliko odstupanja od njega (!) -koji će se ponavljati i ispunjavati lijevu i desnu izložbenu stranu, a s druge reprezentira dobar omjer tekstualnog i slikovnog materijala na legendi, pogotovo u kasnijim tematskim legendama gdje će naglasak biti na vizualnom materijalu. No na jeziku (prestručan [!]) i stilu pisanja tekstova, kako bi bili ako ne lako, a onda barem lakše čitljivi i razumljivi, valjat će još poraditi.

Kao određenu interpretacijsku strategiju moguće je shvatiti opredjeljenje da se prostornim smještajem pojedinih odljeva ukaže na stvarnu funkciju izvornih spomenika. Mnogi od njih bili su dio graditeljskih i grobnih cjelina i zbog toga su smješteni uza zid, dok su odljevi slobodnostojećih spomenika i na izložbi tako postavljeni slobodno u prostoru. O potonjem posebice svjedoči veća i dojmljivija grupa odljeva portreta koji se vodi kao carica Livija, dviju inačica portreta koji se vodi

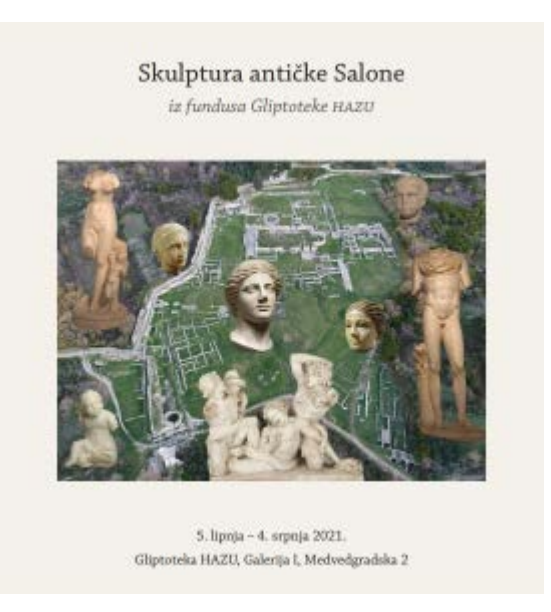

Sl. 5 Detalj plakata izložbe Skulptura anticke Salone. Oblikovanje: Nikola Ivanović.

\section{$\uparrow$}

12

Dojmljiv prikaz izrade posmrtnoga gipsanog odljeva lica Gjure Szabe ostavio je Tihomil Stahuljak u svojoj knjizi Gjuro Szabo djelo jednog života. Usp. nav. dj., I95-197. 
kao carica Plautila te odljev koji se vodi kao kip carskog princa, vezani uz tematsku cjelinu Carski kult u Saloni. (SI. 6) S potonjim odljevom, o kojem je svojedobno kritički pisao i Izidor Kršnjavi,,13 spojena je i bogata naracija koja je ponuđena posjetiteljima na jednom od pokretnih panoa, smještenih između stupovlja dvorane, kao dodatni sadržaj za one koji žele saznati više [!]. U prostoru i s naglašenom estetskom strategijom prezentiran je i odljev Venere Pobjedonosne, čiji je izvornik pronađen u blizini gradskih vrata Porta Andetria. Kao poklon hramu (votivni dar) mogla je služiti, prema istraživačima, dopadljiva mala mramorna skulptura dječaka iz Salone, iskopana tijekom recentnih istraživanja. Njezin odljev Gliptoteka ne posjeduje, no izlaže se kopija spomenute skulpturice, načinjena tehnikom 3D-ispisa i prava je šteta što se to nije interpretativno iskoristilo, pogotovo za približavanje izložbe mlađoj, o tehnologiji ovisnoj populaciji (SI. 7). Naravno, barem se ovdje moglo dozvoliti nesmetano taktilno doživljavanje.

U zapadnom dijelu dvorane odljevi su spojeni s tematskim legendama (posebno se ističu one koje se tiču pogrebne plastike), vezani uza zid i bez one prostorne dinamičnosti kao u istočnom dijelu. Nažalost, zbog količine tematskih jedinica zapravo nema pravih cezura između pojedinih tema, a jednako tako nisu uneseni ni vizualni naglasci, odnosno nisu posebno istaknuti važniji tekstualni i vizualni detalji.

Zato postav završava odličnom interpretativnom strategijom-povezivanjem prošlog i suvremenog putem uvođenja medija filma i stvaranja zaustavnog mjesta gdje se mogu pogledati dokumentarni filmovi o lokalitetu Salone, koje je načinio pravi zaljubljenik u njega, istaknuti hrvatski redatelj Bogdan Žižić. Kako nas je i napustio ove godine, time se na najbolji mogući način oprostilo od njega, a posjetiteljima ostavila mogućnost stvaranja neke završne poruke kako je samo zahvaljujući predanosti muzejskih profesionalaca i istraživača te osviještenih članova lokalne zajednice moguće i konstruirati baštinu jednog lokaliteta, ali i osigurati širenje saznanja o njoj.

U konačnici, izložbom je ostvareno nekoliko vrijednih ciljeva. Prije svega, još se jednom ukazalo na važnost Zbirke antičkih gipsanih odljeva, ali i na važnost Salone kao lokaliteta s kojeg potječe brojna izvorna skulpturalna građa naših i inozemnih zbirki i muzeja čije su odabrane gipsane inačice našle svoje mjesto u Gliptoteci. Izrađen je vrlo dobar katalog izložbe koji je sažeto donio na hrvatskom i engleskom jeziku relevantne suvremene spoznaje o odljevima, ali i o samom lokalitetu, njegovim istraživačima, urbanitetu, najvažnijim građevinama i materijalnim te nematerijalnim ostacima (tematske cjeline koje govore o božanstvima, kultovima, sahranjivanju). Izrađen je i pripadni virtualni sadržaj koji će nastaviti reprezentirati izložbu i nakon njezina zatvaranja. ${ }^{14}$ Napokon, važnim dosegnutim ciljem držimo i iskušavanje različitih interpretativnih strategija u reprezentiranju odljeva-strategije kontekstualizacije, strategije povezivanja prošlog i suvremenog, strategije povezivanja različitih medija-medija filma i medija gipsanih odljeva - te strategije interaktivnosti, koje se mogu u budućnosti primijeniti i u radu na scenariju stalnog postava.

\section{3}

Kršnjavi, „Apollo u zagrebačkom narodnom muzeju”.
Dostupno na: https://salona.netlify.app/ Salona. 


\section{LITERATURA / BIBLIOGRAPHY}

Bauer, Antun. Gipsoteka 1937.-1947. [strojopis]. Zagreb: Gliptoteka HAZU-a.

Cavallero, Elena. Literature review: The adaptive reuse of former industrial buildings as museum spaces: Positive aspects, challenges and difficulties. Dostupno na: https://www.academia.edu/10197277/The_adaptive_reuse_of_former_industrial_ buildings_as_museum_spaces_Positive_aspects_challenges_and_difficulties (pristupljeno 12. kolovoza 2021.).

Čučković, Čedomir. „Što više galerija!”, Muzeologija 31(1994.): 92-95.

Izložba skulpture Antičke Salone iz fundusa Gliptoteke HAZU [virtualna izložba]. Dostupno na: https://salona.netlify.app/Salona (pristupljeno 12. kolovoza 2021.).

Kršnjavi, Izidor. „Apollo u zagrebačkom narodnom muzeju”, Rad JAZU 55 (1881.): 207-219.

Mažuran-Subotić, Vesna. „Dr. Antun Bauer kao osnivač Gipsoteke u Zagrebu”, Muzeologija 31 (1994.): 82-86.

„MASS MoCA Building 6 / Bruner/Cott \& Associates”, 20. studenoga 2017. ArchDaily. Dostupno na: <https://www.archdaily.com/883699/mass-moca-building-6bruner-cott-and-associates> ISSN 0719-8884 (pristupljeno 12. kolovoza 2021.).

Milojković, Aleksandar, Nikolić, Marko. „Museum Architecture and Conversion: From Paradigm to Institutionalization of Anti-museum", Facta Universitatis (Niš) 10, 1 (2012.): 69-83. Dostupno na: http://www.doiserbia.nb.rs/img/doi/0354-4605/2012 /0354-46051201069M.pdf (pristupljeno 12. kolovoza 2021.).

„Pirelli HangarBicocca: History of the Building”. Dostupno na: https:// pirellihangarbicocca.org/en/history-of-the-building/ (pristupljeno 12. kolovoza 2021.).

Stahuljak, Tihomil. Gjuro Szabo djelo jednog života. Zagreb: DPUH, 1995.

Šulc, Branka. „Višestrukost stručnog i znanstvenog djelovanja”, Muzeologija 31 (1994.): 5-8.

„Tectonic Arts. Frank Gehry talks with Julian Rose”, Artforum 56, br. 9 (2018.). Dostupno na: https://www.artforum.com/print/201805/frank-gehry-talks-withjulian-rose-75052 (pristupljeno 12. kolovoza 2021.). 
ŽIVOT UMJETNOSTI 